\title{
GIGANTINE் TIESIOSIOS ŽARNOS ADENOMA. KLINIKINIS ATVEJIS
}

\author{
Albinas Tamošiūnas, Narimantas Evaldas Samalavičius, Algirdas Šlepavičius, Oleg Aliošin \\ Klaipédos universitetine ligonine, Chirurgijos departamentas
}

Raktažodžiai: tiesiosios žarnos adenoma, transanalinė endoskopinė operacija.

\begin{abstract}
Santrauka
Pristatome paciento su gigantine cirkuliaria tiesiosios žarnos adenoma bei sinchronine riestinès žarnos karcinoma in situ klinikini atvejị. Karcinoma in situ pašalinta endoskopiškai, tiesiosios žarnos adenoma pašalinta transanalinès endoskopinès operacijos (TEO) būdu. Histologinis tyrimas neparodė invazyvios karcinomos požymių né viename polipe. Aptariami gigantinių tiesiosios žarnos polipu gydymo ypatumai ir galimybès. Nors pirmenybè teikiama mažai invazyviems metodams, neabejotinų standartų nẻra. Patikimas išvadas padaryti galètų nebent prospektyvinis visų atvejų Europoje auditas.
\end{abstract}

\section{Ivadas}

Nors storosios žarnos adenomos (neoplastinị potencialą turintys kolorektaliniai polipai) - dažna patologija, Vakaru populiacijoje vyresniems kaip 50 metų asmenims pasitaikanti apie 25 proc. atvejų [1], gigantinès cirkuliarios tiesiosios žarnos adenomos gerokai retesnès. Tikslaus gigantinių adenomų dažnio neįmanoma nurodyti vien jau dèl to, kad nèra visuotinai priimtos bendrosios klasifikacijos [2,3]. Dažniausiai gigantinemmis įvardijamos adenomos, didesnès kaip $5 \mathrm{~cm}$, nenurodant krypties - i gyli ar ị plotic. Pristatome ultragigantinès $(>8 \mathrm{~cm})$ cirkuliarios tiesiosios žarnos adenomos atveji, gydytą Klaipèdos universitetinès ligoninès Pilvo ir endokrininès chirurgijos skyriuje.

\section{Klinikinis atvejis}

Pacientas $-74 \mathrm{~m}$. vyras, simptomų nejautè. Anamnezèje - išeminè širdies liga, prieš $11 \mathrm{~m}$. persirgtas miokardo infarktas. Profilaktinio patikrinimo metu FOBT $(+)$. Kitoje gydymo îstaigoje atlikta retrogradine irigoskopija - rastas darinys tiesiojoje žarnoje, traktuotas kaip navikas. Atlikta kolonoskopija - I/V nejautroje apžiūrèta iki aklosios žarnos. Tiesiojoje žarnoje stebimas masyvus, cirkuliarus viliozinis polipas, apie $10 \mathrm{~cm}$ ilgio, apatinio krašto atstumas nuo išangès apie $4 \mathrm{~cm}$. Histologiškai - tubuloviliozinè adenoma.
$20 \mathrm{~cm}$ gylyje rastas apie $2 \mathrm{~cm}$ dydžio NICE2 polipas -histologiškai tubulinė adenoma, esant aukšto laipsnio displazijai (karcinoma in situ).

Dèl invazyvios karcinomos rizikos nuspręsta abu polipus šalinti vienu etapu. Pacientui pirmiausia atlikta endoskopinè polipektomija, endoskopine kilpa pašalintas polipas $20 \mathrm{~cm}$ gylyje, i pagrindą suleidus fiziologinio tirpalo. Procedūra vyko sklandžiai, komplikacijų nebuvo. Kitą dieną atlikta TEO polipektomija. Naudota $15 \mathrm{~cm}$ ilgio TEO platforma (Karl Storz, Tuttlingenas, Vokietija). Pašalintas cirkuliariai tiesiosios žarnos polipas apie $10 \mathrm{~cm}$ ilgio, pogleivio lygyje. Aiškios perforacijos i pilvo ertmę nestebèta. Dèl polipo dydžio - šalinant netilpo i TEO proktoskopą - pašalintas dalimis. Siekiant sumažinti striktūros tikimybę, proksimalinis ir distalinis rezekcijos kraštai suartinti pavienėmis $3 / 0$ poliglikolio siūlèmis. Operacijos trukmè 7:15 val., po operacijos gydytas RITS, stebetas laikinas CK kilimas iki 1764 U/1, nesant kliniškai reikšmingo suspaudimo sindromo. 2 pooperacinę parą grąžintas ị skyrių. Kontrolinėje apžvalginejje pilvo rentgenogramoje laisvo oro nestebèta, tačiau CRB pakilo iki $150,8 \mathrm{mg} / \mathrm{l}$. Skirta parenterinè mityba, antibiotikoterapija ceftriaksonu 1,0x2 ir metronidazoliu $0,5 \times 3$. Peritonito požymių nebuvo, nekarščiavo, CRB per 4 paras sumažèjo iki $26,9 \mathrm{mg} / 1$, leukocitozė $4,72 \times 10^{\wedge} 9 / 1$. Išrašytas 5 pooperacinę parą, rekomendavus tęsti peroralinę antibiotikoterapiją cefuroksimu $0,5 \times 2$ ir metronidazoliu $0,5 \times 2$ dar 5 paras. Histologinis tyrimas iš riestinès žarnos: tubulinè adenoma su intramukozine vidutiniškai diferencijuota (G2) adenokarcinoma. pTis. Rezekcijos kraštuose adenokarcinomos nèra. Histologinis tyrimas iš tiesiosios žarnos: storosios žarnos plokščia tubulinė adenoma M8263/0. Po 1 mėnesio pacientas apklaustas telefonu - nusiskundimų neturi, tuštinasi gerai, nekarščiuoja.

Histologiškai storosios žarnos adenomos skirstomos ị tubulines (75-85\% atveju), tubuloviliozines (10-25\%) ir viliozines (5\%) [1]. Piktybinis potencialas priklauso ne tik nuo histologinio tipo, bet ir nuo adenomos dydžio. Mažesniame nei $1 \mathrm{~cm}$ polipe karcinomos tikimybe neviršija 5 proc., tačiau didesniame nei $2 \mathrm{~cm}$ polipe invazyvios karcinomos tikimybė yra iki 50 procentų [1]. Paprastai storosios žarnos polipai 


\section{4}

simptomų nesukelia, tačiau stambūs vilioziniai tiesiosios žarnos polipai gali pasireikšti kraujavimu tuštinantis, gleivingomis išskyromis, tenezmais [1]. Retais atvejais masyvių viliozinių tiesiosios žarnos polipų hipersekrecija gali sukelti dehidrataciją, ryškų elektrolitų pusiausvyros sutrikimą ir prerenalinị inkstų nepakankamumą - tai vadinama McKittrick Wheelock sindromu $[4,5]$.

\section{Diskusija}

Nedidelès kolorektalinès adenomos paprastai nustatomos ir pašalinamos kolonoskopijos metu [1]. Visgi plokšti stambūs polipai endoskopine kilpa pašalinami sunkiai, didelẻ polipo fragmentacijos ir neradikalaus pašalinimo tikimybè. Tiesiojoje žarnoje šalia išangès esantys polipai gali būti pašalinami transanaliai. $1984 \mathrm{~m}$. G. Buess pristate transanalines endoskopines operacijas (TEM/TEO) [6]. Šios operacijos, kartu su vèlesnèmis ịvairiomis transanalinèmis minimaliai invazyviomis metodikomis (TAMIS), endoskopine mukozektomija (EMR) ir endoskopine submukozine disekcija (ESD) [8] yra pagrindiniai tiesiosios žarnos polipų šalinimo būdai - priklausomai nuo ligoninès turimos ịrangos ir patirties. Šie metodai leidžia polipus pašalinti vienu bloku, jei šalinama T1 karcinoma - toks gydymas gali būti pakankamas [9], tačiau gigantiniai, ypač cirkuliarūs, tiesiosios žarnos polipai yra tam tikras iššūkis. Viena vertus, patologija gerybinè, todèl pageidautinos mažai invazyvios, mažesnès apimties operacijos, kurios saugesnès pacientui, komplikacijos retos. Kita vertus, gigantinių, ypač cirkuliarių, adenomų pašalinimas techniškai itin sudètingas, ne visada įmanoma pašalinti vienu bloku, ypač jei šalinama pogleivio lygyje. Gana dažnai polipai siekia rezekcini kraštą - nuo 9,7 iki 30,7 proc. atveju [9]. Atliekant viso sienos storio eksciziją, pašalinimas vienu bloku labiau tikètinas, tačiau suartinti ir susiūti rezekcijos kraštus nenaudojant tempimo ne visada imanoma, be to, dideja pilvaplèvès perforacijos rizika. Nors tai nèra labai didelè komplikacija $[8,10]$, tačiau perforacija turi būti pastebèta ir sandariai užsiūta. TEO cirkuliari sandari siūlè irgi techniškai sudètinga, reikalaujanti didelès patirties [7]. Jei šalinant mažesnius polipus, palikti atvirą defektą yra priimtina taktika, tai cirkuliarus žarnos sienos defektas (nepriklausomai nuo to, ar yra pogleivio lygyje, ar viso sienos storio) ateityje sukels randinę striktūrą. Dubenyje gali būti ịkritusių žarnų kilpų, ypač jei operacijos metu pacientas nèra Trendelenburgo padètyje, jos irgi gali būti pažeistos, atliekant lokalų cirkuliarios tiesiosios žarnos adenomos šalinimą [7]. Lokaliai šalinant cirkuliarios tiesiosios žarnos adenomą, laparoskopija ar net laparotomija labai tiketina ir traktuotina ne kaip nepageidaujamas įvykis, bet kaip logiškas operacijos etapas $[8,10]$. Nèra klaida ir cirkuliarų viliozini polipą traktuoti kaip galimai invazyvią karcinomą ir atlikti radikalią rezekcinę operaciją - net jei histologinis tyrimas nerodo piktybiškumo požymių. Kaip minèta, tikimybè, kad gigantiniame vilioziniame polipe gali būti invazyvios adenokarcinomos židinys, siekia 50 proc., todèl dalis autoriu $[11,12]$ rekomenduoja atlikti radikalią rezekciją pagal onkologinius principus. Idealu būtų piktybiškumą patikslinti dar iki operacijos, deja, jei biopsija invazijos nepatvirtina, vaizdinè diagnostika - magnetinio rezonanso tomografija (MRT) bei endoskopinis ultragarsinis tyrimas (EUG) nèra itin naudingi. Kaip parode F. Letarte ir bendraautorių tyrimas [13], atliekant MRT gigantinių adenomų atveju, visada radiniai įvertinami kaip gerokai toliau pažengęs navikinis procesas, reikalaujantis gerokai didesnès apimties ar net kompleksinio gydymo. Jei pooperaciniame histologiniame tyrime rasta 8 karcinomos in situ bei $4 \mathrm{~T} 1$ adenokarcinomos, tai priešoperacinis MRT visus navikus vertino kaip T2-3 adenokarcinomas. Labiau pasitikint MRT nei biopsija ir klinikiniu vertinimu, visiems pacientams turètų būti taikomas perteklinis gydymas, su visomis galimomis komplikacijomis ir liekamaisiais reiškiniais, pavyzdžiui, anastomozès nesandarumu ar žemos tiesiosios žarnos rezekcijos sindromu (LARS). MRT polinkị ị hiperdiagnostiką patvirtina ir asmeninè patirtis. Endoskopinis ultragarsinis tyrimas pasirode kiek tikslesnis, tačiau taip pat pervertino pusę visų auglių. Jei vaizdiné diagnostika invazijos i pogleivị neranda - jos greičiausiai ir nèra, bet jei invazija randama - jos gali iš tikrujų ir nebūti arba yra ženkliai mažesnè. Jei po tiesiosios žarnos polipo pašalinimo paaiškètų, kad navikas vis dẻlto piktybinis ir operacijos radikalumas nepakankamas $(>\mathrm{T} 1$ navikas, pogleivio invazija $>$ SM1, ypač - limfovaskuline invazija), būtų reikalinga radikali rezekcinè tiesiosios žarnos operacija [1-3,8]. Mūsų atveju situaciją sunkino antrasis polipas riestineje žarnoje, kuris po polipektomijos galejo pasirodyti esantis invazyvi adenokarcinoma, dèl kurios reikètų antru etapu atlikti radikalią operaciją. Pasirinkome TEO polipektomiją pogleivio lygyje, aukodami galimybę pašalinti polipą vienu bloku. Operacinio preparato histologinis tyrimas toki pasirinkimą pateisino, bent jau kol kas - polipe nei invazyvios, nei in situ karcinomos nerasta, po operacijos praejus mènesiui, paciento savijauta gera, tuštinimasis be sutrikimų.

\section{Išvada}

Cirkuliarių gigantinių tiesiosios žarnos adenomų gydymo standarto nèra. Nors mažai invazyvioms operacijoms teikiama pirmenybè, gydymo taktika parenkama individualiai, atsižvelgiant ị paciento būklę, polipo ypatybes, esamą įrangą ir gydytojų chirurgų ir (ar) endoskopuotoju įgūdžius. Tokie atvejai pasitaiko retai ir nèra bendros visuotinai priimtos klasifikacijos, todèl surinkti pakankamą atvejų skaičių ir padaryti patikimas išvadas galètų nebent prospektyvinis visų atvejų Europoje auditas. 


\section{Literatūra}

1. Bains L, Lal P, Vindal A, Singh M. Giant villous adenoma of rectum - what is the malignant potential and what is the optimal treatment? A case and review of literature. World Journal of Surgical Oncology 2019;17:109. https://doi.org/10.1186/s12957-019-1650-4

2. Levic K, Bulut O, Hesselfeldt P. Transanal endoscopic microsurgery for giant polyps of the rectum. Tech Coloproctol 2014;18:521-527. https://doi.org/10.1007/s10151-013-1069-9

3. Serra-Aracil X, Flores-Clotet R, Mora-Lopez L, Pallisera-Lloveras A, Serra-Pla S, Navarro-Soto S. Transanal endoscopic microsurgery in very large and ultra large rectal neoplasia. Techniques in Coloproctology 2019;23:869-876. https://doi.org/10.1007/s10151-019-02071-1

4. Caron M, Dubrule CE, Letarte F, Lemelin V, Lafleur A. McKittrick-Wheelock Syndrome Presenting with Acute Kidney Injury and Metabolic Alkalosis: Case Report and Narrative Review. Case Reports in Gastrointestinal Medicine 2019;Article ID 3104187. https://doi.org/10.1155/2019/3104187

5. Van der Pool AEM, de Graaf EJR, Vermaas M, Barendse RM, Doornebosch PG. McKittrick wheelock syndrome treated by transanal minimally invasive surgery: a single-center experience and review of the literature. Journal of Laparoendoscopic \& Advanced Surgical Techniques 2018;28(2):204-208. https://doi.org/10.1089/lap.2017.0195

6. Buess G, Hutterer F, Theiss J, Böbel M, Isselhard W, Pichlmaier H. A system for a transanal endoscopic rectum operation. Chirurg 1984;55: 677-80.

7. Arezzo A, Arolfo S, Allaix ME, Bullano A, Miegge A, Marola S, Morino M. Transanal endoscopic microsurgery for giant circumferential rectal adenomas. Colorectal Disease 2016;18(9):897-902. https://doi.org/10.1111/codi.13279

8. Arezzo A, Arolfo S, Cravero F, Migliore M, Allaix ME, Morino M. Which treatment for large rectal adenoma? Preoperative assessment and therapeutic strategy. Minimally Invasive Therapy \& Allied Technologies 2014;23(1):21-27. https://doi.org/10.3109/13645706.2013.833117

9. Dulskas A, Kilius A, Petrulis K, Samalavičius NE. Transanal endoscopic microsurgery for giant benign rectal tumours: is large size a contraindication? Int J Colorectal Dis 2017; 32(12):1759-1761. https://doi.org/10.1007/s00384-017-2910-9

10. Mege D, Petrucciani N, Maggiori L, Panis Y. Peritoneal perforation is less a complication than an expected event during transanal endoscopic microsurgery: experience from 194 consecutive cases. Tech Coloproctol 2017;21(9):729-736. https://doi.org/10.1007/s10151-017-1676-y

11. Rickenbacher A, Bauerfeind P, Rössler F, Turina M. Sequential endoscopic and surgical removal of giant rectal adenomas extending to the dentate line. Techniques in Coloproctology 2018;22(5):379-381. https://doi.org/10.1007/s10151-018-1794-1

12. Roriz-Silva R, Andrade AA, Ivankovics IG. Giant rectal villous adenoma: Surgical approach with rectal eversion and perianal coloanal anastomosis. International Journal of Surgery Case Reports 2014;5(2):97-99.

https://doi.org/10.1016/j.ijscr.2013.12.003

13. Letarte F, Drolet S, Laliberte AS, Bouchard P, Bouchard A. Transanal endoscopic microsurgery for rectal villous tumours: Can we rely solely on preoperative biopsies and the surgeon's experience? Can J Surg Vol 2019;62(6):454-459.

https://doi.org/10.1503/cjs.012416

\section{GIANT RECTAL ADENOMA. CASE REPORT}

A. Tamošiūnas, N.E. Samalavičius, A. Šlepavičius, O. Aliošin Keywords: rectal adenoma, transanal endoscopic operation. Summary

We are presenting a case of a man with giant circular rectal adenoma and in-situ carcinoma of sigmoid colon. The latter was removed endoscopically, while for rectal adenoma was performed transanal endoscopic operation (TEO). Histological examination did not found signs of invasion in both polyps. Controversies regarding tactics are discussed. Although minimally invasive approaches are favorized, there is no robust standard in treatment of giant rectal adenomas. Prospective european audit could give reliable conclusions.

Correspondence to: albinas.tamosiunas@gmail.com

Gauta 2021-10-20 